http://dx.doi.org/10.4314/jae.v18i2.7

\title{
Factors affecting performance of Facilitators in the Fadama 111 Development
} Project in Enugu State, Nigeria

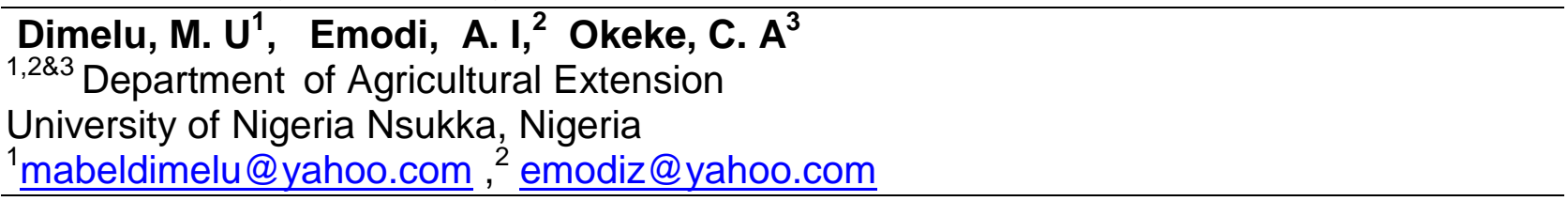

\section{Abstract}

The study examined issues associated with the performance of facilitators in Fadama 111 Development Project. All the (68) facilitators in the Fadama 111 Development Project were used. Questionnaire was used for data collection and analysis conducted using descriptive statistics. Majority of the facilitators were females (51.6\%) with mean age of 39 years and working experience of 8 years in extension. A greater proportion (64.0\%) had degree with specialization in agriculture (50.9\%) and social sciences and other disciplines (49.0\%). The respondents ranked interaction with supervisors $(M=3.98)$, methods of human /staff communication ( $M=3.56)$, monitoring and evaluation system $(M=3.32)$, timeliness of allowance $(M=3.22)$, coordination and supervision techniques used $(M=3.20)$, provision of training facilities, $(M=3.20)$ as the first six organizational factors influencing performance. Job- related issues included pressure to increase output/quality of work $(M=3.67)$, Supervisors expectations $(M=3.57)$, staff mobility $(M=3.52)$, timeliness of input $(M=3.49)$, inadequate training opportunity $(M=3.28)$, conflicting orders $(M=3.21)$ and others. Also employeerelated issues associated with performance of facilitators were involvement in religious activities $(M=3$. 37), academic background $(M=3.34)$ health status $(M=$ 3.26), extended family burdens $(M=3.13)$, listening to TV programmes $(M=$ 3.12), relationship with spouse $(M=2.98)$ and others. The study recommends that development planners and administrators should ensure organizational type, personnel development and management systems that could promote and foster enabling working environment, improve capability and staff welfare for enhanced performance of extension workers.

Key words: Facilitator, performance, Fadama, project, and development.

\section{Introduction}

Over the years Nigerian government has introduced and implemented several policies and programmes aimed at revamping the agricultural sector (Ajibefun and Aderinola, 2004). Some of such programmes include the National Accelerated Food Production Programme (NAFPP-1973), River Basin Development Authority (RBDA-1975), Operation Feed the Nation (OFN, 1976), Agricultural Credit Scheme (ACGS-1977), Green Revolution (GR-1980), Agricultural Development Programme (ADP-1985), Directorate of Food, Roads and Rural Infrastructure (DFRRI-1987), the National Land Development Authority (NLDA-1992) (Ajayi 2001; Daudu, 2008). Others include the First National Fadama Development Project (1991), National Special Programme for Food Security (2003), National Fadama Development project (2004). 
The National Fadama Development Project (NFDP) came on board as a result of the success recorded by the small scale irrigation projects carried out by the Agricultural Development Programs (ADPs) in fadama areas (irrigable land usually low-lying plains underlay by shallow aquifers found along Nigeria's major river systems). Such lands are especially suitable for irrigated production and fishing, and traditionally provide feed and water for livestock, but its potential is only partially developed (World Bank, 2008). The project was implemented in phases (Fadama 1, 11 and 111). Fadama I Development Project was implemented between 1992 and 1998 (Akinola, 2003). It concentrated on the production of arable crops only and covered few states in the country. Fadama II project widened the focus and the horizon of operation among fadama resource users by supporting both farm and non-farm activities linked to fadama resources. Similarly, Fadama III project is a follow up to the successful Fadama II project with development objective aimed to sustainably increase the incomes of fadama users by about $60 \%$ and also targeted the poor and vulnerable (Nkonya, et. al., 2010).

However, both phases of fadama project anchor on facilitation for demand-driven investments and empowerment of local community groups. The central principle or idea of the community demand driven (CDD) approach of the Fadama project is to produce competent facilitators who will live in the communities with farmers making sure they have access to relevant information and resources (Enugu State Fadama Handbook, 2010). The approach empowers beneficiaries' communities to draw up the community development plans through participatory and socially inclusive appraisal with the assistance of community facilitators.

Facilitation with community driven approach has become more popular and widely used to implement agricultural development programmes in the country. The purpose of facilitation under the National Fadama III Development Project is to motivate Fadama Community Association (FCAs) to take charge of their own development agencies and to stimulate local development. The facilitator has responsibilty to ensure that the planning process is truly participatory; and in the case of Fadama 111, to see that the small scale projects identified as the economic interest venture/activity by the farmers are implemented in accordance with guidelines and safeguard policies (SPCO. Enugu, 2010). Thus, the facilitators have unique responsibility of shaping the course of project, relating directly with the beneficiaries at the community level (Ingawa, et al., 2004). Invariably, the success of programme depends on a large scale adoption of community demand driven approach by farmers and brilliant performance of facilitators (Donegier et al, 2001; Gillepsie, 2004). Moreover, with greater expectations from successive agricultural development programmes sometimes as a result of increasing challenges in the agricultural sector and expansion scope of coverage as in Fadama 111, the workload and expectations from facilitators also increase diametrically. Thus, the issues associated with performance of field staff or facilitators in programmes become pertinent. The study therefore, examined factors affecting the performance of facilitators in Fadama 111 development programme. The specific objectives were to:

1. describe the personal characteristics of facilitators in Fadama 111 Development

Project and

2. examine factors affecting performance of facilitators in the programme. 


\section{Methodology}

The study was carried out in Enugu State, Nigeria. The State lies on longitude $6^{\circ} 30^{\prime} \mathrm{N}$ and latitude $7^{0} 30^{\prime} \mathrm{E}$. The State has a total land area of $7,161 \mathrm{~km}^{2}$ and a population of $3,267,837$ people (NPC, 2006 ) The population of the study consisted of facilitators in the Enugu State Fadama III Development Project. All the facilitators in Enugu State Fadama III Project was used, giving a total of 68 facilitators. Data for the study were collected from the respondents by use of questionnaire. The instrument for data collection was divided into two sections based on the objectives of the study. Firstly the respondents were requested to indicate the sex, age (years), family size, academic qualification, year of experience in extension (years), area of specialization and others. Factors that affect performance of facilitators were considered at three important levels namely: organizational, job-related and employee- related factors. To ascertain the organizational factors that affect performance of facilitators, respondents were asked to indicate on a five-point Likert- type scale of "no extent ( 1), very little extent (2), little extent ( 3 ), great extent (4) , very great extent (5), the extent to which each of the 16 different organizational items affect their performance.

The job-related factors of the facilitators were measured by asking the respondents to indicate the extent to which 23 different job-related issues influenced performance on a five-point Likert-type scale as follows: "no extent ( 1), very little extent (2), little extent ( 3 ), great extent (4), very great extent (5). Lastly, the employee- related factors were measured by eliciting information on the respondents perception of the extent to which 20 items on employee -related factors affect their performance. A five point Likert type scale of "no extent ( 1), very little extent (2), little extent (3), great extent (4), very great extent (5) . Data were analysed with descriptive statistics, mean scores and standard variation. Variables with mean scores $\geq 3$ were regarded as major factors and $<3$ considered minor issues affecting performance of facilitations. Also the variables were ranked based on the mean.

\section{Results and Discussion}

\section{Socioeconomic characteristics of respondents}

A greater proportion $(60 \%)$ of the respondents were between 30 and 39 years., while $28.4 \%$ were within $40-49$ years. Only about $5 \%, 5 \%$ and $2 \%$ of the respondents were within the age range of 20 to 29,50 to 59 years and above 60 years, respectively. The mean age of the respondents was 39 years. The respondents are within active and productive years. Ideally young extension professionals will be able to put in more years of productive service if the conditions of service are favourable (Ekumankama, 2005). The females accounted for $52 \%$ of the facilitators in the programme. The gender distributions skewed towards female, probably because of high gender sensitivity of most current development programmes. This could be attributed to increasing role of women in agricultural activities. The proportion of married $(50 \%)$ and single $(50 \%)$ facilitators were equal, indicating participation of both young and elderly in the programme. Fifty percentage of the facilitators had between 1 and 5 household size, while those who had between 6 and 10 persons accounted for $50 \%$. The mean family size was 5 persons.

Table 1 shows that majority (64\%) of the facilitators had the Bachelor degree and about $16 \%$ had higher national diploma (HND). A lesser proportion (4.6\%) had masters degree, 
while about $5 \%$ had ordinary national diploma (OND). The results show that all the facilitators are literate with majority as university graduates. This is partly an evidence of increasing high knowledge structure of the labour force in the agricultural sector, perhaps in response to growth in technological advancement in the sector. Higher level of education has been largely associated with a higher level of career commitment and performance of workers. Literature show that poor training and low educational level of extension staff contribute to the failure of many agricultural extension activities (Farouk and Okpokpo, 1997: Asiabaka, 2002). Invariably, the more educated the field level extension workers, the higher the level of job performance and extension service as a whole (Blum, 1991).

Furthermore the facilitators $(70.7 \%)$ had between 1 and 5 years of experience in extension and $12.5 \%$ had 6 to 10 years of experience. Only about $8 \%, 5 \%$ and $3 \%$ of the respondents had 21 to 25,16 to 20 and above 30 years of experience in extension. Most $(83 \%)$ of the respondents has worked in extension for the past ten years. The average years of experience in extension was 8 years. The result suggests that most of the facilitators may have started extension work with the inception of Fadama Development Project and few others have been working in extension agency before joining the services of the project. However, only about $16 \%$ of the facilitators had basic academic background in extension. Other areas of academic background of the facilitators were agriculture $(19.2 \%)$, social science $(11.8 . \%)$, agricultural education $(16.0 \%)$ and other discipline $(37.2 \%)$. This means that about half of the facilitators have no background in agriculture and more than half have no extension orientation. This does not only cast doubt on the degree of adherence to World Back criteria for selection of facilitators but reveals the political and human factors in the implementation of the project. On the other hand it increases the burden of in-service training to close the knowledge/skill gaps which often are not easy to come by due to challenges of funds. 
Table 1: Distribution of respondents by socioeconomic characteristics

\begin{tabular}{ll}
\hline Socio-economic characteristics & Percentage $\mathbf{( n = 7 0 )}$ \\
\hline Age & \\
$20-29$ & 5.0 \\
$30-39$ & 0.0 \\
$40-49$ & 28.4 \\
$50-59$ & 5.0 \\
Above 60 & 1.6 \\
Sex & \\
Male & 48.4 \\
Female & 57.6 \\
Marital status & \\
Single & 50.0 \\
Married & 50.0 \\
Household size & \\
1-5 & 50.0 \\
6-10 & 50.0 \\
$11-15$ & - \\
Education qualification & \\
OND & 4.7 \\
HSC & 1.6 \\
HND & 15.6 \\
NCE & 1.6 \\
B.Sc, or B.Agric & 64.1 \\
MSc & 10.7 \\
Others & 1.7 \\
Years of experience & \\
1-5 & 70.7 \\
-10 & 12.5 \\
11-15 & - \\
16-20 & 4.7 \\
21-25 & 7.6 \\
Above 30 & 1.7 \\
Area of specialization & 2.7 \\
Social science & \\
Agricultural extension & 11.8 \\
Other areas of agriculture & 15.7 \\
Agricultural education & 19.3 \\
Other discipline & 16.0 \\
& 37.2 \\
\hline
\end{tabular}

\section{Organizational factors for performance of facilitators}

Table 2 shows the mean and ranking of the indices of organizational factors affecting performance of facilitators and extension workers in general. The performance of the respondents was mostly affected by level of interaction with supervisor $(M=3.98)$, methods of human relationships ( $M=3.56)$, monitoring and evaluation system $(M=3.32)$, timeliness of allowance $(M=3.22)$, coordination and supervision techniques used $(M=3.20)$ and provision of training facilities $(M=3.17)$. Other factors of significant for the performance of facilitators were provision of basic logistics including kit $(M=3.17)$, lines of organizational communication $(M=3.17)$ and performance feedback $(M=3.11)$. Factors of less importance included provision of incentives $(M=2.92)$, concern for the Staff Social Welfare $(\mathrm{M}=2.89)$, provision of office facilities/management $(\mathrm{M}=2.80)$, collaboration mechanism $(M=2.07)$, strategies for recruitment $(M=2.11)$, and redress of grievance 
$(M=2.48)$. However, the standard deviation of majority of the variables was high indicating wide variance in perception of the factors. The result indicates that quality of facilitators and their output in terms of performance are functions of the interaction of several factors. In other word, effective performance of facilitators can be inhibited by poor institutional/organization framework, lack of infrastructure/logistic support and motivational packages which provides for staff interaction, communication, motivation and role performance. This largely agrees with Ekumankama (2005) who reported that organizational confidence indices for performance of extension worker are provision of basic logistic, concern for staff welfare, supervision techniques and others. According to Glisson and Hemmelgram (1998) creating a positive organizational climate is more effective in improving performance effectiveness than increasing the actual services available to clients. Factors like planned supervision, efficient monitoring and evaluation system, provision of feedback, good personnel management strategies and less bureaucratic/flexible organizational structure, not only increase confidence of facilitators, boost morale and job satisfaction, but further enhance staff development. Institutionally, provision of enabling environment for optimal performance particularly basic logistic as the right of the facilitators is contained in the facilitators' handbook in Fadama III Project, but the problem has been with implementation. Therefore, the degree of organisation preparedness for effective implementation of agricultural programmes is critical for personnel performance and subsequent realization of objectives of interventions.

Table 2: Mean distribution of organizational factors affecting performance of facilitators

\begin{tabular}{llll}
\hline Organisational Factors & Mean & $\begin{array}{l}\text { Std. } \\
\text { deviation }\end{array}$ & Rank \\
\hline $\begin{array}{l}\text { The level of interaction between you and } \\
\text { supervisor }\end{array}$ & 3.98 & 0.88 & 1 \\
$\begin{array}{l}\text { Method of staff communication } \\
\text { Monitoring and evaluation system }\end{array}$ & 3.56 & 0.84 & 2 \\
Timeliness of allowance & 3.32 & 1.05 & 3 \\
Coordination and supervision techniques & 3.22 & 1.32 & 4 \\
Provision of training facilities & 3.20 & 0.98 & 5 \\
Provision of basic logistics (working kit) & 3.20 & 1.35 & 5 \\
Performance feedback & 3.17 & 1.28 & 6 \\
Concern for staff social welfare & 3.11 & 0.96 & 7 \\
Provision of office facilities & 2.89 & 1.15 & 8 \\
Provision of incentive/timely promotion & 2.80 & 1.75 & 9 \\
Redressal of grievance & 2.79 & 1.21 & 11 \\
Recruitment strategies & 2.48 & 1.03 & 12 \\
Collaboration mechanism & 2.21 & 1.20 & 13 \\
\hline
\end{tabular}

Job related factors for performance of facilitators

The respondents ranked pressure to increase quality of work $(M=3.70)$ pressure to increase output $(M=3.67)$, supervisors expectation $(M=3.57)$, mobility problem $(M=3.52)$ and too much work $(M=3.50)$ as the first five job-related variables that affect performanablece (Table 3). This could be as a result of the work targets set for the facilitators, as these targets are part of instruments for measuring the facilitators' 
performance. According to Cole (1993) job performance appraisal criteria are either personality oriented or result oriented. However, within each of these orientations, appraisers still have to measure individual performance on the job. Too much workload whether in terms of quantitative and qualitative overload largely determines the level of performance and personnel job satisfaction. Also the issue of staff mobility is critical in the implementation of development programmes, given the poor road network of rural areas and the dispersed settlement of farmers. Most major activities/demonstrations or projects (eg fadama 111 sub-project) are sited on different rural farmlands which must be monitored and supervised. This requires that facilitators travel long distance to provide necessary services for the execution of these subprojects, most times on very difficult terrain. The problem is even more complex where the facilitators are females, who may not have the capability to ride motorcycles on such difficult terrain thus limiting effectiveness in executing function.

Irregular allowance $(\mathrm{M}=3.49)$ and timeliness of input $(\mathrm{M}=3.49)$, lack of promotion opportunities $(M=3.33)$, inadequate training $(M=3.28)$, conflicting orders $(M=3.21)$, insufficient authority $(M=3.06)$ ranked $6^{\text {th }}-11^{\text {th }}$ factors that affected performance of the facilitators. The results point to the need for motivation of personnel, clear line of authority and span of control in the organization of development programme. Most extension professionals/facilitators especially in public extension organizations are grossly underpaid, ill-equipped and poorly motivated. This adversely affects the performance of extension staff and extension services as a whole. With respect to issues of training Farouk and Okpokpo, (1997) opined that attendance to induction and regular in-service training as well as regular promotion of extension staff affect the workers performance on the job. Staff training is one of the crucial aspects of staff development aimed at optimal staff utilization, productivity, commitment, motivation and growth. Undoubtedly, where training is lacking, productivity is hampered.

Furthermore, other factors of significant to performance of personal were insufficient organization communication $(\mathrm{M}=3.03)$, conflicting demands of personal and work life $(\mathrm{M}=$ 3.00) and other. The result reveal the need for functional organizational structure which provides for effective communication channel fundamental for execution of responsibility in an organization. The institutional framework on which a development programme is anchored distinctively marks out the type of structure that fosters communication, authority and control. 
Table 3: Mean distribution of job-related factors affecting performance of facilitators.

\begin{tabular}{llll}
\hline Job-related indices & Mean & Std deviation & Rank \\
\hline Pressure to improve quality of work & 3.70 & 1.02 & 1 \\
.Pressure to increase output & 3.7 & 1.17 & 2 \\
Supervisors expectations & 3.57 & 0.95 & 3 \\
Mobility problems & 3.52 & 1.12 & 4 \\
Too much work & 3.50 & 1.10 & 5 \\
Timeliness of input & 3.49 & 1.18 & 6 \\
Heavy workload affecting quality & 3.44 & 1.14 & 7 \\
Lack of promotion opportunities & 3.33 & 1.33 & 8 \\
Inadequate training opportunity & 3.28 & 1.24 & 9 \\
Conflicts disorder & 3.21 & 1.24 & 10 \\
Insufficient authority & 3.06 & 1.32 & 11 \\
Insufficient organizational communication & 3.03 & 1.15 & 12 \\
Conflicting demands of personal and work life & 3.00 & 1.25 & 13 \\
Not sure of career prospect & 2.83 & 1.24 & 14 \\
Fear of retrenchment & 2.75 & 1.16 & 15 \\
Not understanding performance evaluation & 2.27 & 1.15 & 16 \\
Procedure of accessing assets & 2.56 & 0.99 & 17 \\
Non-acceptance by others & 2.53 & 1.13 & 18 \\
Political capture & 2.52 & 1.19 & 19 \\
Criteria for beneficiary selection & 2.37 & 1.18 & 20 \\
Strategies for users' participation & 3.30 & 1.01 & 21 \\
\hline
\end{tabular}

\section{Employee related factors affecting facilitators in Enugu state NFDP III}

Table 4 shows the mean and ranking of employee- related factors associated with performance of facilitators. Involvement in religious activities $(M=3.37)$, health status $(M=3.36)$, reading literature $(M=3.35)$, individuals academic background $(M=3.34)$ and social status ( $M=3.26$ ) were the five topmost factors affecting performance of facilitators. These factors could either inhibit or enhance performance of facilitators. For instance, engaging in religious activities and good social relation are often useful behavior in dealing with job-related stress, however if not controlled could jeopardize employees productivity. Also involvement in positive activity to increase social status is often a life style for many workers as they attempt to deal with the problems of everyday life. Similarly, reading and acquisition of basic academic background enhance capability for the designated job and boost performance. On the contrary, poor training and low educational level of extension staff could forestall performance of personnel in carrying out extension activities. The more educated the field level extension workers, the higher his level of job performance and extension service as a whole. Health status also determines availability and the intensity of involvement in extension and facilitation activities.

The respondents expressed that extended family burdens $(M=3.13)$, listening to local, national and international news $(M=3.12)$, relationship with spouse $(M=2.98)$, proximity to client $(M=2.90)$, spending time with children and siblings $(M=2.87)$, spending time with friends $(M=2.85)$, physical exercise $(M=2.82)$, watching favourite TV programmes 
$(M=2.73)$, involvement in social meetings $(M=2.73)$ and others affect their performance. These factors appear to be common stress- coping behaviours employed against jobrelated stress. In addition, factors such as listening to radio, television and proximity to clients keep the facilitators updated on relevant and useful information; and could ease the problem of transportation and regular visit to farmers. Relatively, the results agree with Ekumankama, (2005) who concluded that certain behaviours developed by extension professionals to enable them cope favourably with the negative effects of the job-related factors are assumed to have effects on performance.

Table 4: Mean distribution of employee-related factors affecting performance of facilitators

\begin{tabular}{|c|c|c|c|}
\hline Employee-related indices & Mean & SD & Rank \\
\hline Involvement in religious activities & 3.37 & 1.15 & 1 \\
\hline Health status & 3.36 & 1.09 & 2 \\
\hline Reading literature & 3.35 & 1.08 & 3 \\
\hline Academic background & 3.34 & 1.26 & 4 \\
\hline Social status & 3,26 & 0.96 & 5 \\
\hline Extended family burden & 3.13 & 1.16 & 6 \\
\hline $\begin{array}{l}\text { Listening to Local, National and International } \\
\text { News }\end{array}$ & 3.12 & 1.26 & 6 \\
\hline Relationship with spouse & 2.98 & 1.23 & 8 \\
\hline Proximity to client & 2.90 & 0.83 & 9 \\
\hline Spending time with children and siblings & 2.87 & 1.26 & 10 \\
\hline Spending time with friends & 2.85 & 1.16 & 11 \\
\hline Physical exercise & 2.82 & 1.04 & 12 \\
\hline Involvement in social meetings & 2.73 & 1.07 & 13 \\
\hline Size of family & 2.72 & 1.26 & 14 \\
\hline Spending time with spouse & 2.70 & 1.15 & 15 \\
\hline Doing house cores & 2.68 & 1.31 & 16 \\
\hline $\begin{array}{l}\text { Engaging in other income generating activities } \\
\text { e.g.gardening, poultry, clothe/bags/shoes } \\
\text { marketing }\end{array}$ & 3.63 & 1.18 & 17 \\
\hline Going for shopping & 3.37 & 1.08 & 18 \\
\hline Language barrier & 2.24 & 1.29 & 19 \\
\hline
\end{tabular}

\section{Conclusion}

Performance of facilitators is a function of the organizational, job and employee- related factors. Thus, issues on organizational/institutional framework, infrastructure/logistic support and motivational packages for effective personnel management and performance should be among key priorities in planning and implementing development programmes. Also facilitators need to cultivate positive social and recreational behavior/altitudes to cope with job-related stress and enhance performance. Largely, these factors depend on the administrative capability of the planners, administrators, the infrastructural and policy environment of the nation. The study recommends that development planners and administrators should ensure organizational structure, personnel training and management systems that could promote and foster enabling working environment, improve capability and staff welfare for enhanced performance of extension workers. 
There should be adequate budgetary allocation for provision of major infrastructure/logistic supports and extra cost incurred in the course of executing extension activities. Extension workers should build and promote positive social and recreational behaviours through effective personnel management strategies and orientation.

\section{References}

Ajayi, C. O. A. (2001). The role of adult education in rural poverty alleviation in Nigeria. A long essay submitted to the Department of Adult Education, Universty of Nigeria, Nsukka. pp 38-50.

Ajibefun, I. A and Aderinola, E. A. (2004). Determinants of technical efficiency and policy implication in traditional agricultural production: Empirical study of Nigeria food crop farmers. Final report presented at bi-annual research workshop of African Economic Research Consortium, Nairobi, Kenya.

Akinola, M. O. (2003). The performance of fadama users association under the national fadama development project phase One, Nigeria. A Ph.D Thesis, Ahmadu Bello Univerty, Zaria pp. 3-73.

Asiabaka, C. C. (2002). Agricultural Extension :A Handbook for Development Practitioners. Omoku, River State, Molsyfem United Services.

Blum, A.(1991). What can be learned from a comparism of the agricultural knowledge system? The case of Netherland and Isreal. Agricultural Ecosystem and the environment, .33:325-339.

Cole, G.A. (1993). Management: Theory and Practice. London, DP publications Ltd.

Daudu, S. (2008). Determinants of role performance effectiveness among facilitators in the second national fadama development project in Nigeria. $\mathrm{PhD}$ thesis, Department of Agricultural Extension, University of Nigeria Nsukka, Nigeria.

Dongier, P., Domelen, Van. J., Ostrom, E., Rizvi, A., Wakeman, W., Bebbington, A., Alkire, S., Esmail, T. and Polski, M. (2001). Community-driven development, In : J. Kiugman (ed). A Source book for poverty reduction strategies, Vol. 1. Washington, DC.

Ekumankama, O. O. (2005). Comparative analysis of job performance of extension professionals in Abia and Akwa Ibom States' Agricultural Development Programmes,

Ph.D Thesis, Department of Agricultural Extension, University of Nigeria, Nsukka.

Enugu State Fadama Coordinating Office. (2010). Handbook on National Fadama III Development, Enugu State. Publication ,EN-SFCO, Enugu.

Farouk, U. and Okpokpo, S. S. (1997). Determinants of jop performance of extension agents in Akwa lbom State of Nigeria. Journal of Agricultural Extension, Vol.1:3440. 
Gillepsie, S. (2004). Scaling up community-driven development: $A$ Synthesis of Experience.

Food and Nutrition Division Discussion Paper No. 181. Washington, DC: International Food Policy Research Institute.

Glisson, C and Hemmelgarn, A. (1998). The effects of organizational climate and inter organizational coordination on the quality and outcomes of Children's Service System,

Child Abuse and Neglect, 22 (5) :401-421

Ingawa, S. A., Oredipe, A. A., Idefor, K and Okafor, C. (2004). Facilitators Project Implementation Manual. Second National Development Project (Fadama II). Federal Ministry of Agriculture and Rural Development. Abuja, Nigeria.

National Population Commission (NPC) (2006). Human population figures of 2006 census in Nigeria, Abuja. http://www.npc.gov. accessed $12^{\text {th }} 2010$.

Nkonya E. H. Markel ova, Kato E, Alomolaron A, Shetima A. G, Ingawa S. (2010). Baseline Report of Fadama III Impact Assessment Study. International Food Policy Research Institute, Washington, DC USA; 2010;. p.Viii.

World Bank, (2008). Project Appraisal document on third National Fadama Development (fadama

Project.www.officialwebsite/kogistategovernment/ofnigeria.stateagenciesandboard/ adp.mht retrieved 16th October, 2012. 